\title{
PALYNOLOGICAL EVIDENCE OF HUMAN ACTIVITY ON THE GULF OF GDAŃSK COAST DURING THE LATE HOLOCENE**
}

\author{
Grażyna Miotk-Szpiganowicz, Joanna Zachowicz and Szymon Uścinowicz
}

Polish Geological Institute-National Research Institute, Branch of Marine Geology (80-328 Gdansk, 5 Kościerska St.)

E-mail: grazyna.miotk-szpiganowicz@pgi.gov.pl; joanna.zachowicz@ pgi.gov.pl; szymon.uscinowicz@pgi.gov.pl;

\section{A B S T R A C T}

The Gulf of Gdańsk is located in the southern part of the Baltic Sea. The shores of the Gulf are dominated by the sandy barriers which have developed in front of the Vistula Lagoon and the Vistula Delta Plain to the south-east and south and in front of the Puck Lagoon in the north-west such as the Hel Peninsula. Cliffs occur on the western coast of the Gulf. Neolithic settlements around the coast of the Gulf of Gdańsk are mainly located at the foot of the upland slope and on the Vistula Spit and the Vistula Delta and are closely related to the rise and displacement of the shoreline during the Late Holocene. Pollen analyses of the sediment cores from the Vistula Delta, the Vistula Lagoon and the coast of the Puck Lagoon allow four anthropogenic phases to be distinguished in the area of the Gulf of Gdańsk. It has been shown that the first indicators of an early husbandry economy in the vicinity of the Gulf of Gdańsk appeared in the Atlantic Period. Pollen grains of plants related to this kind of human activity - those of the goosefoot family (Chenopodiaceae), motherwort (Artemisia), sorrel (Rumex) are present and the first pollen grains of the plantain (Plantago lanceolata) also appear. The second anthropogenic phase of Neolithic settlement is one of the best investigated cultures. This is the Rzucewo Culture. Pollen analyses indicate increasing human activity at the beginning of the Subboreal Period. The preserved traces of fauna show that the seal hunting and fishing economy was preferred. Radiocarbon dating of archaeological artifacts indicates the beginning of the settlement at ca. 2400 B.C. (ca. 4400 years B.P.) (Król 1997). The altitude of peat and marine mollusks' shells and their radiocarbon age shows that during the Early Subboreal Period the water level rose from ca. $2.8 \mathrm{~m}$ to $1.1 \mathrm{~m}$ below the present-day sea level. The date of the beginning of the seal hunters' settlement correlates well with the period when the shores of the Puck Lagoon approached their recent position. The development of the Neolithic settlement on the Puck Bay coast as well as those on the Vistula Delta, where the main activity was related to amber processing, seal hunting and fishing, clearly shows a close relationship to the sea-level rise. The occurrence of the third and fourth settlement phases was related to the high sea-level stands in the Subboreal and Subatlantic Periods (post-Littorina, Late Holocene regressions) but their character was still strongly related to the coastal environments. The settlement was connected with the dry habitats whose areas increased after the development of the barriers. In the area of the Vistula Delta, settlement conditions depended mainly on the stages of the delta's development. On the shores of Puck Bay, however, the intensity of settlement was closely related to the water level changes.

\section{RESUMO}

O Golfo de Gdansk está localizado na parte sul do Mar Báltico. As praias do Golfo são dominadas por barreiras de areia formadas em frente à Lagoa do Vistula e à planície deltaica do Vistula pelo lado sudeste-sul, e em frente a Lagoa de Puck a noroeste, tal como acontece na Peninsula de Hel. Paredões costeiros ocorrem, por sua vez, na costa oeste do Golfo. Assentamentos neolíticos ao redor da costa do Golfo de Gdansk estão localizados principalmente no sopé do talude e no Delta do Vistula, sendo estritamente relacionados com a elevação do nível do mar e as decorrentes variações da linha de costa ao longo do Holoceno Tardio. Análises do polen do sedimento obtido nos corers do Delta do Vistula, Lagoa do Vistula e Lagoa Puck permitiram distinguir 4 fases antropogênicas para a área do Golfo de Gdansk. Foi visto que os primeiros indicadores da economia baseada em criação de animais domésticos nas vizinhanças do Golfo apareceram no Período Atlântico. Foram encontrados grãos de polen das plantas relacionadas com esse tipo de atividade humana - familia Amaranthaceae (Chenopodiacea), "motherwort" (Artemisia), "sorrel" (Rumex) - aparecendo também os primeiros grãos de polen de Plantago lanceolata. O assentamento neolítico da cultura Rzucewo, situado na costa oeste da Lagoa de Puck, é um dos que tem sido melhor investigados. As análises de polen indicam um incremento da atividade humana no início do Período Sub-boreal. Os traços preservados da fauna mostram que a caça da foca e a economia pesqueira eram as atividades preferidas. A datação radiocarbônica dos artefatos arqueológicos indicam que o começo do assentamento deve ter ocorrido há c.a. de 2400 AC (KROL, 1997). A altura das turfas e das conchas de moluscos marinhos, além de suas idades determinadas por radiocarbono, mostram que durante o Periodo Sub-boreal Inferior o nível da água aumentou entre 1,0 e 2,5 m em relação ao nível atual. A data do inicio do assentamento dos caçadores de foca correlaciona-se bem com o período em que as praias da Lagoa de Puck se aproximaram de sua condição quase atual. O desenvolvimento do assentamento Neolítico nas costas da Baía de Puck, assim como no Delta do Vistula, onde a caça às focas e pesca ocorreram embora a atividade principal fosse relacionada ao processamento do âmbar, mostram uma clara relação com o aumento do nível do mar. Esses assentamentos podem ser relacionados não só com a migração humana, efetuada no sentidodo do interior para a praia, mas muito provavelmente foi o resultado de uma retração causada pelas mudanças da linha de costa. A ocorrência das terceira e quarta fases do assentamento, durante o período Subatlântico foram relacionadas ao baixo posicionamento do nível do mar. Na área do delta do Vistula as condições de assentamento dependeram principalmente dos estágios de desenvolvimento do Delta. Entretanto, nas praias da Baía de Puck a intensidade do assentamento esteve relacionada às mudanças do nível das águas.

Descriptors: Palynology, Sea level, Geoarchaeology, Neolithic, Subboreal, Gulf of Gdańsk.

Descritores: Palinologia, Nível do mar, Geoarqueologia, Neolítico, Sub-boreal, Golfo de Gdansk.

(*) Paper presented at the INTERNATIONAL GEOLOGICAL CORRELATION PROGRAM PROJECT NO. 526 - RISKS, RESOURCES, AND RECORD OF THE PAST ON THE CONTINENTAL SHELF: MINING LATE QUATERNARY GEOLOGICAL EVIDENCE, 2. 2008, Natal, UFRN. 


\section{INTRODUCTION}

For many years, the shores of the Gulf of Gdańsk have constituted an area of paleogeographical investigation including research into sea-level change (BOGACZEWICZ-ADAMCZAK; MIOTK, 1985; BOGACZEWICZ-ADAMCZAK et al., 1999; ZACHOWICZ et al., 1982; ZACHOWICZ; KĘPIŃSKA， 1987; MIOTK-SZPIGANOWICZ, 1997; LATAEOWA; BADURA 1998, UŚCINOWICZ; MIOTK-SZPIGANOWICZ, 2003). Archaeological research has also been conducted at many sites in this area providing information on the development of settlement during various archaeological periods (KRÓL, 1991, 1997, 2002, 2003; POMIAN et al., 2000).

The development of the coast of the Gulf of Gdansk during the Holocene has been closely connected with sea-level oscillations. Particularly significant changes have occurred during the last 5000 years, when the rise in sea-level has been slow. Transgressive and regressive oscillation phases made their mark in a manner similar to that evident in southern Scandinavia during the Atlantic Period (BERGLUND, 1971; DIGERFELDT, 1975).

Underwater archaeological sites of the Mesolithic and Neolithic ages are known from the coast of the Western Baltic (GRAMSCH, 2002; LÜBKE, 2002). However, no such sites have yet been discovered along the Polish Baltic coast. But both Neolithic archaeological sites and those related to later periods are evident along the coast of the Gulf of Gdańsk (Fig. 1).

Their location and the period of their existence were closely related to shoreline displacement.

The main goal of this research was to determine how human economic activity has been related to changes in sea-level during the last ca. 5000 years of the history of the Gulf of Gdańsk.

\section{The Location AND Characteristics OF THE STUdy AREA}

The study area is located in the southern part of the Baltic Sea, along the coast of the Gulf of Gdańsk and in the Vistula Delta (Fig. 1). The Gulf has an area of ca. $5000 \mathrm{~km}^{2}$ and a maximum depth of 108 $\mathrm{m}$. In the extreme western part of the Gulf lies Puck Bay - protected from the more open waters by the approximately 32-km-long Hel Peninsula. Puck Lagoon is separated from the shallowest, northern part of Puck Bay by a semi-submerged barrier. The southeastern part of the Gulf of Gdańsk is fringed by the roughly 55-km-long Vistula Spit which separates the Vistula Delta and the Vistula Lagoon from the Baltic Sea (Fig.1). The Polish section of the coast of the Gulf of Gdańsk is ca. $170 \mathrm{~km}$ long. Along its western edge the Gulf is bordered by morainic uplands and icemarginal valleys. The morainic uplands border directly on the sea and frequently form coastal cliffs, whose total extension is of ca. $27 \mathrm{~km}$. A wetland (saltmarsh) coast ca. $17 \mathrm{~km}$ in length is formed along the coastal areas where the ice-marginal valley floors lie at $0.5-$ $1.0 \mathrm{~m}$ above sea level. Barriers (dune coasts) with dunes up to $35 \mathrm{~m}$ in height and ca. $114 \mathrm{~km}$ in length occur along the southern and south-eastern coast of the Gulf of Gdańsk. About $12 \mathrm{~km}$ of the coast is occupied by harbour constructions and breakwaters.

The Vistula Delta (Fig. 1) is situated on the southern coast of the Gulf of Gdańsk. The inland part of the delta extends over an area of ca. $1800 \mathrm{~km}^{2}$ and the submerged part covers ca. $700 \mathrm{~km}^{2}$. The inland part of the delta rises to an altitude of about $10 \mathrm{~m}$ a.s.l., where the Vistula branches into two main streams, and sinks to $1.8 \mathrm{~m}$ b.s.l. in its north-eastern part.

The development of the main geological and morphological features of the Gulf of Gdańsk, including Puck Bay and Puck Lagoon, is related to the last glaciation and deglaciation processes (KRAMARSKA et al. 1995, 2003; UŚCINOWICZ, 1995). Subsequent to deglaciation ice-marginal valleys and morainic uplands existed on adjacent land and extended into the north-western part of the Gulf of Gdańsk. During the late Glacial and early Holocene (ca. $12000-8500$ years B.P. - Fig. 2), marshy, swampy and limnic areas predominated in the coastal region of the Gulf of Gdańsk. This part of the Gulf, which is now lying $20 \mathrm{~m}$ under the water, has undergone marine transgression during the last 8000 years. At the beginning of the Subboreal Period (ca. 5 000 years B.P. - Fig. 2), the sea almost entered this region, and previously freshwater lakes were transformed into what is now the brackish Puck Lagoon (KRAMARSKA et al., 1995, 2003; UŚCINOWICZ; MIOTK-SZPIGANOWICZ, 2003).

The formation and development of the Vistula Delta was a consequence of transgression and regression events which occurred during the late Glacial and Holocene in the recent inland area, as well as on the seafloor. The recently submerged part of the delta is comprised of two main units: the older one formed during the late Glacial and early Holocene, and the younger one formed during the Littorina Sea (middle Holocene) transgression and which together constitute a complex system of delta-front and prodelta beds of different ages (UŚCINOWICZ; ZACHOWICZ, 1992).

Similarly, the inland deltaic sediments also consist of two lithostratigraphic units. The lower unit consists of two beds. The older bed contains mediumand fine-grained sands with inserts of Preboreal and Boreal oxbow deposits. The younger bed consists of muds and peats, formed between 8000 and 6300 
years B.P. The upper unit also contains two beds. Channel facies of fine sand with numerous inserts of phytogenic material prevail in the older bed. The younger bed of the upper unit is dominated by muds. In the north and east of the area deltaic deposits of the upper unit are replaced by marine (lagoonal) sediments. The lagoonal deposits in the Vistula River
Delta area are younger than 6300 years B.P. (MOJSKI, 1988, 1990).

The Littorina (Atlantic, middle Holocene, Flandrian - Fig. 2) transgression led to the emergence of sand barriers (spits) in front of the delta and lagoon. The barrier migration rate was dependent on the amount of material supplied by the river as well as the rate of sea-level rise.

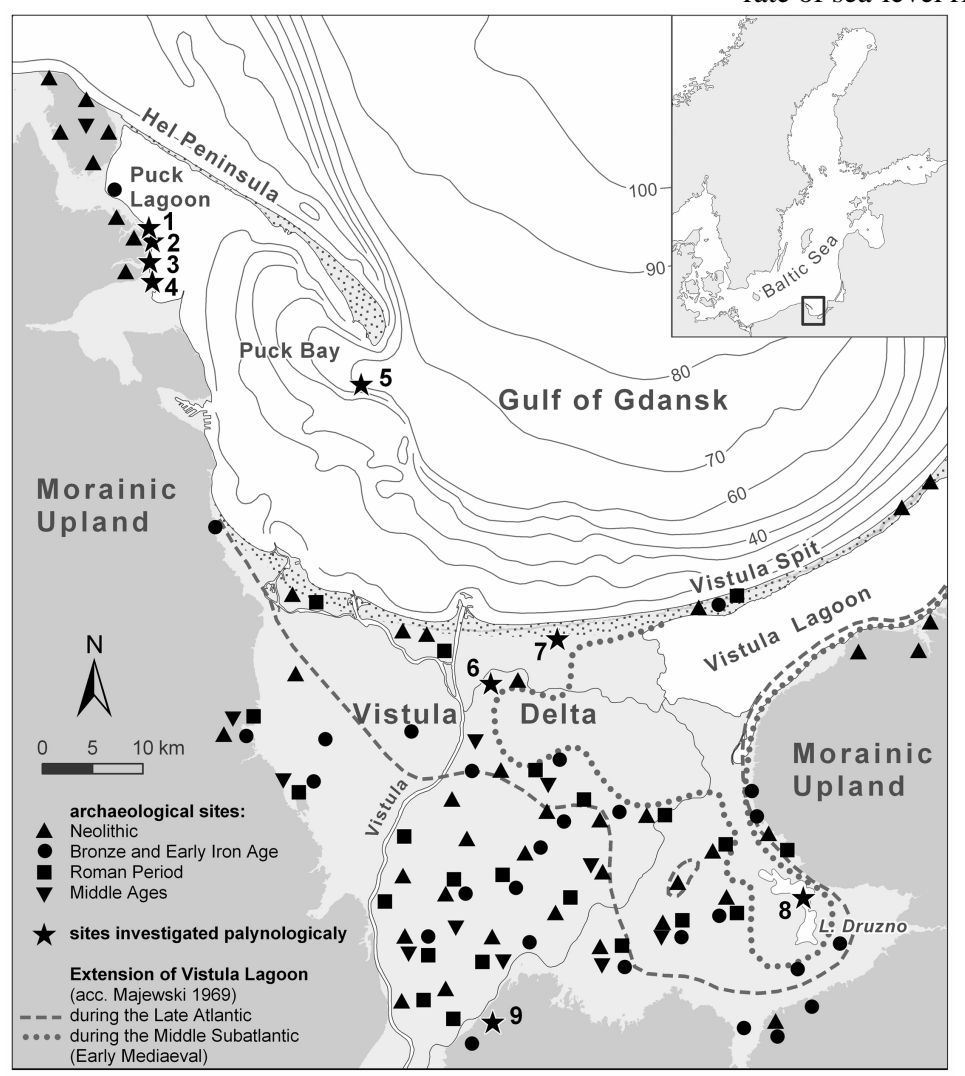

Fig. 1. Location of the study area and archaeological sites on the shores of the Gulf of Gdańsk Sites investigated palynologically: 1 Rzucewo - trench, 2 - Rzucewo Headland, 3 -. Gizdepka, 4 - Beka, 5 - Puck Bay 6/2001, 6 Niedźwiedziówka, 7 - Stegna, 8 Druzno Lake, 9 - Węgry.

Fig. 2. Comparison of eustatic ocean level rise (BLANCHON; SHAW, 1995) and relative sea level rise in the southern Baltic (USCINOWICZ, 2003). Holocene periods: AT - Atlantic, SB - Subboreal, SA Subatlantic.

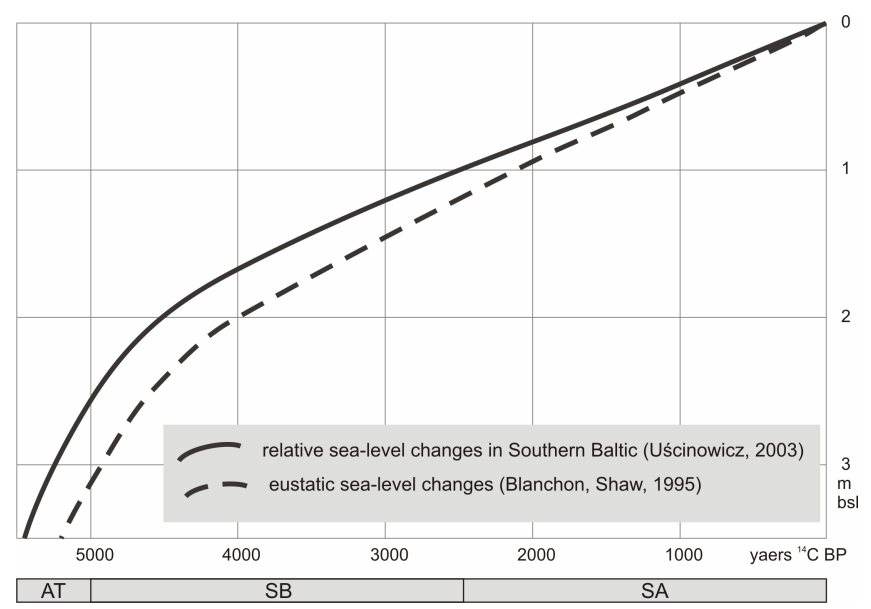




\section{The Water Level Changes}

The southern Baltic relative sea-level curve for the last 8000 years after the Baltic became permanently connected with the ocean (UŚCINOWICZ, 2003) shows a similarity to global eustatic sea-level curves (e.g. MÖRNER, 1976, 1980; FAIRBANKS, 1989; BLANCHON; SHAW, 1995, BARD et al., 1996). According to the smooth relative sea-level curve for the southern Baltic (Uścinowicz 2003) and Puck Lagoon (UŚCINOWICZ; MIOTKSZPIGANOWICZ, 2003; UŚCINOWICZ et al., 2007), at the end of the Atlantic Period (Fig. 2) the sea level was ca. $2.8 \mathrm{~m}$ lower than at present, while 1000 years later (ca. 4000 years B.P.) it rose to about 1.8 $1.9 \mathrm{~m}$ below its present level. These findings suggest that the Littorina Sea transgression (Middle Holocene, Atlantic, Flandrian) ended ca. 5000 years BP and finally ceased at ca. 4000 years BP. During the second part of the Subboreal Period and during the Subatlantic (Fig. 2) the sea level rose very slowly and the rise pattern was very sensitive to all possible climatic fluctuations and neotectonic crustal movements.

More detailed investigations of the Puck Lagoon suggest that the sea level could have changed, in a cyclical manner with a periodicity of ca. 1000 years and an amplitude of 0.2-0.5 m, with peaks at ca. 3900 years B.P., 2900 years B.P., 1900 years B.P. and 900 years B.P. (KRAMARSKA et al., 2003; ZACHOWICZ et al., 2004, UŚCINOWICZ et al., 2007). As the smoothed models of sea-level curves for the Gulf of Gdańsk and Puck Lagoon are similar, it could be assumed that the cyclicality recognized in Puck Lagoon may have occurred along the entire Gulf of Gdańsk coast. Similar cyclicality of sea-level change is recorded in the Atlantic and Subboreal sediments on the southern Swedish coasts (BERGLUND, 1971; DIGERFELD, 1975). The periodicity of the transgressive-regressive phases identified in southern Sweden (BERGLUND, 1971; DIGERFELDT, 1975; MÖRNER, 1976, 1980) has been set at between 1600 and 500 years.

\section{Materials ANd Methods}

Palynological investigations were performed at nine sites located around the Gulf of Gdansk (Fig. 1). These sites are located: on the shore of the presentday Puck Lagoon (Rzucewo trench, Rzucewo Headland, Gizdepka, Beka), in the area of Puck Bay (Puck Bay 6/2001), in the Vistula Delta (Niedźwiedziówka, Stegna), at Lake Druzno (Druzno) and on the morainic upland which fringes the Vistula
Delta in the south (Wegry). Palynological analysis was the main method of investigation. Peat and silt sediments were examined. The palynologically investigated samples were taken from cores by vibrocorer (Puck Bay 6/2001), the Ejkelkamp piston corer $80 \mathrm{~cm}$ in length and with an internal diameter of $4 \mathrm{~cm}$ (Rzucewo Headland, Gizdepka, Beka) and peat sampler (Lake Druzno and Węgry) or directly from archaeological exploration holes (Rzucewo trench and Niedźwiedziówka) and a geological trench (Stegna).

The samples for microscopic tests were prepared in accordance with the generally accepted principles (FAEGRI; IVERSEN 1978, BERGLUND, 1979). The minerogenic sediments were treated with cold HF acid for a minimum of 48 hours. 1000 pollen grains of trees and shrubs (AP) have been counted in each sample. The results obtained were presented as simplified percentage diagrams drawn using POLPAL software (Figs 3 - 11). The basis for the calculation of percentage values was the sum of pollen grains of trees and shrubs (AP) and terrestrial herbaceous plants (NAP). The share of pollen grains of aquatic and marshland plants, spores and Pediastrum cenobia, was calculated in relation to the sum of AP + NAP. Pollen diagrams contain the curves for the particular tree species and species connected with human impact and cumulative curves for Wet meadow indicators, Human indicators, Telmatophytes and Limnophytes. The grouping and qualification of taxa for the Wet meadow indicators cumulative curve was undertaken using the division suggested by Behre (1981). This curve included such taxa as: Asteroideae, Cichorioideae, Ranunculaceae, Umbelliferae, Plantago major-media, Lychnis-type, Rumex acetosa, Mentha-type, Filipendula, Succissa pratensis. The anthropogenic phases characteristic of each of the sites were identified.

The radiocarbon dating of organic sediments, mainly peat, was performed at the Radiocarbon Laboratory of Gliwice Technical University. Due to the small number of radiocarbon dates, the anthropogenic phases were correlated mainly on the basis of the changes in the tree curves. The palynological information at hand was compared with diagrams of the most fully documented sites on the Baltic coast (TOBOLSKI, 1987, 1989; LATAŁOWA, 1989; LATAŁOWA; TOBOLSKI, 1989). The most helpful were the isopollen maps of tree species (RALSKA-JASIEWICZOWA et al., 2004).

Results distinguish regional settlement phases for the area of the Gulf of Gdansk coast (Fig. 12). These are plotted on the Puck Lagoon relative sea-level curve providing a picture of the relationship between the increase in intensity of human economic activity and sea level oscillations (Fig. 13). 


\section{THE PHASES OF HUMAN IMPACT}

Based on the results of palynological investigations, four phases in the increase in human economic activity were distinguished on the coasts of the Gulf of Gdańsk, (Fig. 11).

\section{The 1st Phase}

The oldest traces of human economic activity, in the sediments investigated, were registered at the Rzucewo Headland site, (Fig. 3) and possibly at the Puck Bay 6/2001 site (Fig. 4). Ruderal plants (species sensitive to increases in nitrification) appeared in the pollen diagrams, including: the goosefoot family (Chenopodiaceae), which can also mark sea-level changes, motherwort (Artemisia) and sorrel (Rumex). Single occurrences of pollen grains of Cerealia-type and plantain (Plantago lanceolata), the taxon strictly connected with animal husbandry, may be the result of a very low intensity of human economic activity. The dominance of mixed deciduous forests with species composition characteristic of the climatic optimum (Quercus, Ulmus, Tilia) proves that the first traces of human activity in this area occurred towards the end of the Atlantic Period (Figs 3, 4) and probably were connected with the Paraneolithic culture. The age is confirmed at the Rzucewo Headland site by the $14 \mathrm{C}$ date: $5520 \pm 70$ years B.P. of the peat layer which contains pollen grains of human indicators.
At that time the more extensive wetlands were occupied by marshland communities and forests with alder (Alnus), hazel (Corylus), elm (Ulmus) and an admixture of ash (Fraxinus). Lime (Tilia - Fig. 8) and oak (Quercus - Figs 3, 4) co-existed with pine (Pinus) in the drier habitats on the morainic uplands.

\section{The 2nd Phase}

Traces of the next settlement culture are visible in the Rzucewo trench (Fig. 5), at Niedźwiedziówka (Fig. 6) and probably also at Druzno Lake (Fig. 7). Rzucewo and Niedźwiedziówka are simultaneously sites of archaeological investigation.

The results of the palynological investigations indicate a small increase in the importance of ruderal plants such as the motherwort (Artemisia), the goosefoot (Chenopodiaceae) and sorrel (Rumex), the presence of single grains of plantain (Plantago lanceolata), and cereals (Cerealiatype) and the first grains of wheat (Triticum). This may be evidence of a not-too-intensive development of both animal husbandry and farming connected, according to archaeological data, with the Rzucewo Culture. This seal-hunter culture of lasted from ca. 4400 - 3700 years B.P. (KRÓL, 2003).

In the vegetation cover, mixed deciduous forests with oak (Quercus), lime (Tilia) and hazel (Corylus) prevailed. The increase of alder (Alnus), telmatophytes (Fig. 6) or limnophytes (Fig. 7) at the end of this phase could be related to a rise in the sea level.

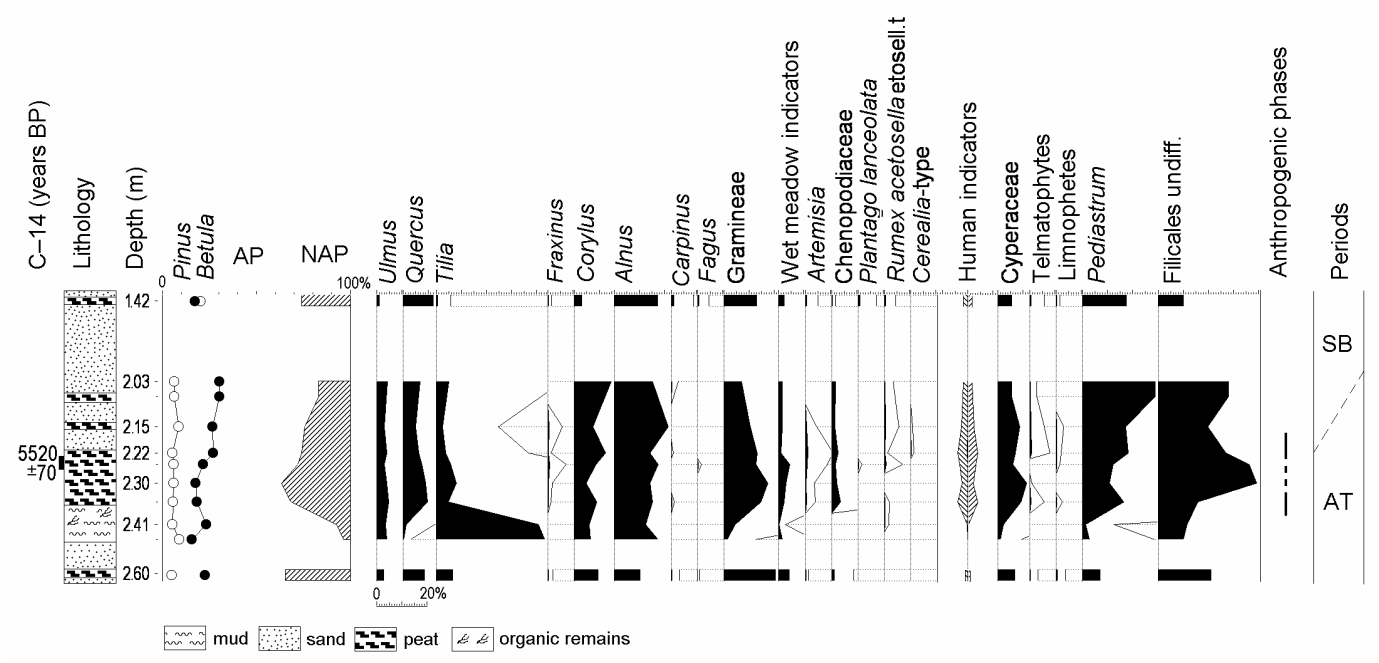

Fig. 3. Rzucewo Headland (site altitude $-0.5 \mathrm{~m}$ a.s.1.). Simplified pollen diagram 


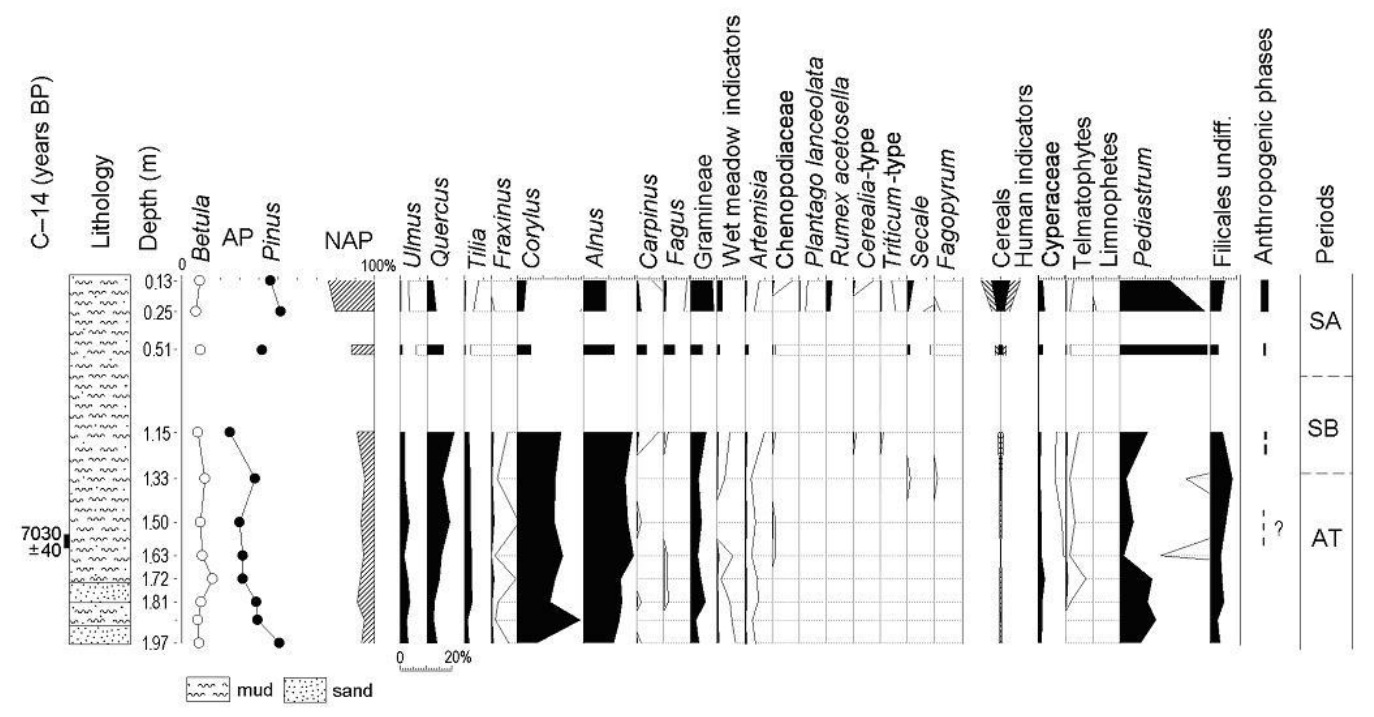

Fig. 4. Puck Bay 6/2001 (water depth - 62.0 m). Simplified pollen diagram.

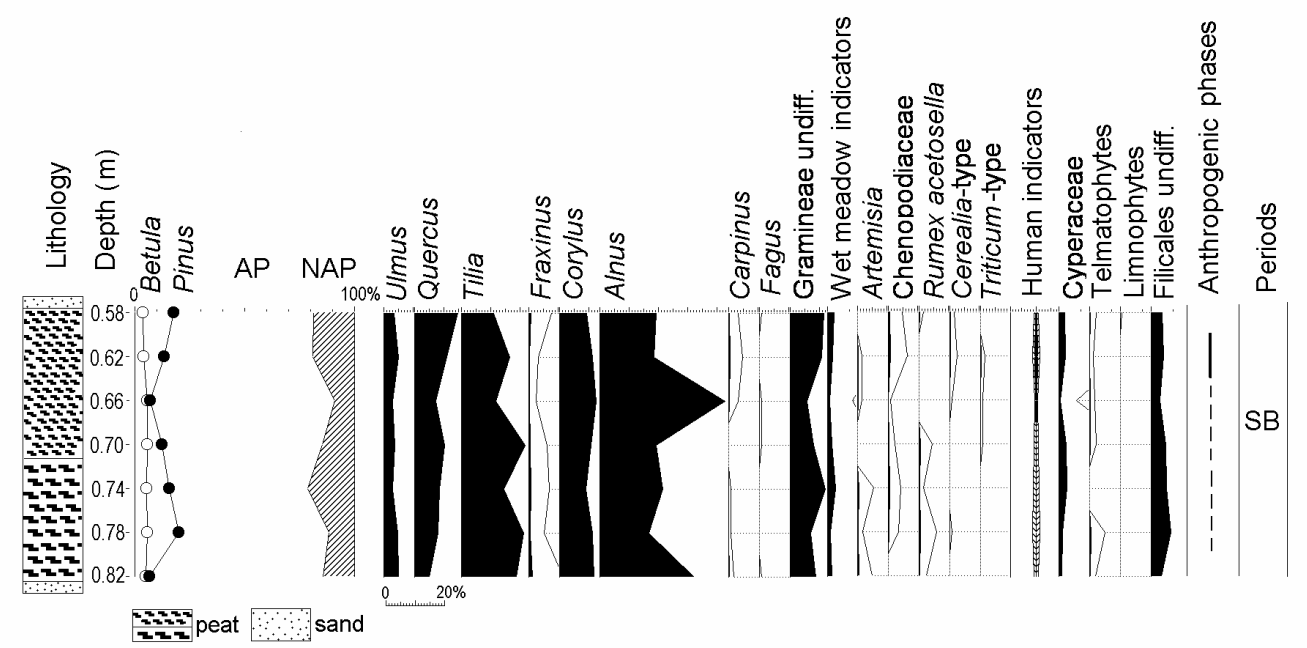

Fig. 5. Rzucewo trench (site altitude - $0.6 \mathrm{~m}$ a.s.1.). Simplified pollen diagram.

The 3rd Phase

This phase is clearly marked at three sites: Niedźwiedziówka (Fig. 6), Druzno (Fig. 7), Gizdepka (Fig. 8) and part of it is probably also visible at Puck Bay 6/2001 (Fig. 4). This phase is related not only to an increase in the amount of pollen grains of ruderal plants (Artemisia, Chenopodiaceae) and plants connected with the development of animal husbandry, such as plantain (Plantago lanceolata), but most of all - cereals. Apart from pollen grains of Cerealia-type, increased amounts of wheat (Triticum) pollen grains appear. At the same time, a clear drop in deciduous tree curves occurs, which suggests that the increase in the intensity of agriculture was associated with the considerable deforestation of the area. The palynological data shows that this phase started most probably towards the end of the Subboreal period and continued at the beginning of the Subatlantic Period. No doubt it can be linked to the Lusatian Culture and Pomeranian Culture, which followed it (LATAŁOWA, 1982, 1994, 1995). These two cultures, according to archaeological data, developed during the end of the Bronze Age and the beginning of the Iron Age (OSTOJA-ZAGÓRSKI 1974; LATAŁOWA 1997). 


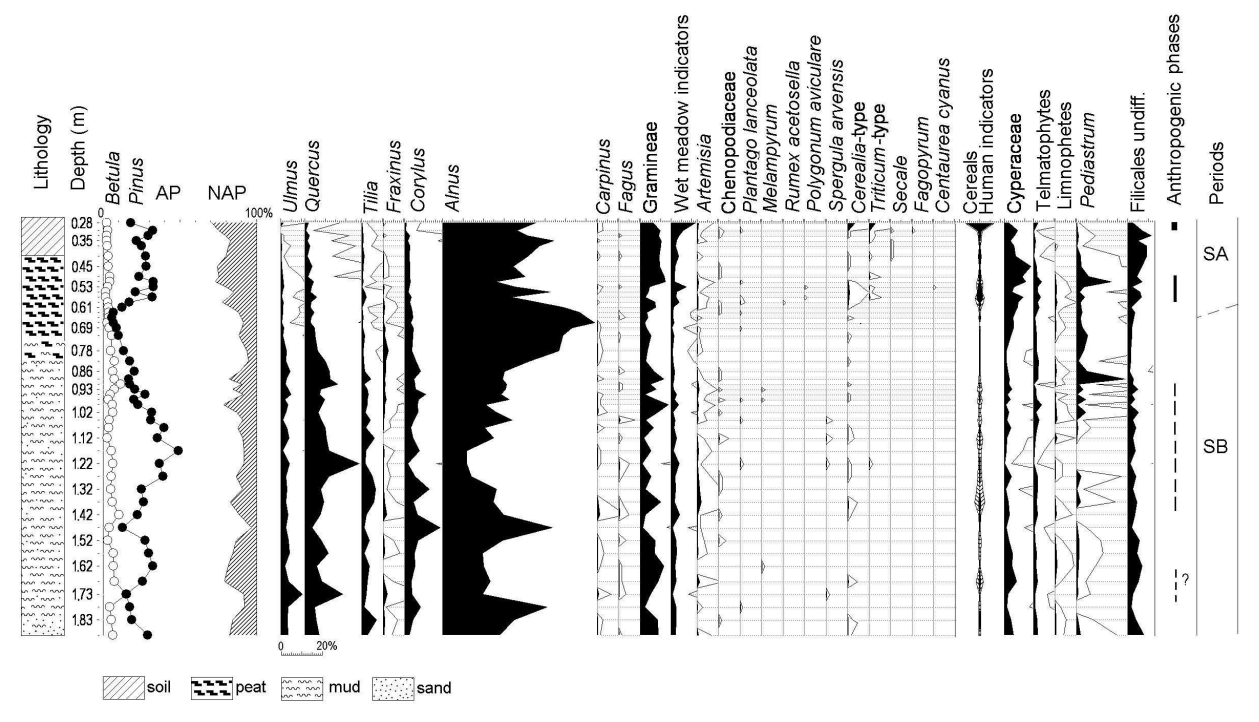

Fig. 6. Niedźwiedziówka (site altitude $-0.5 \mathrm{~m}$ b.s.1.). Simplified pollen diagram.

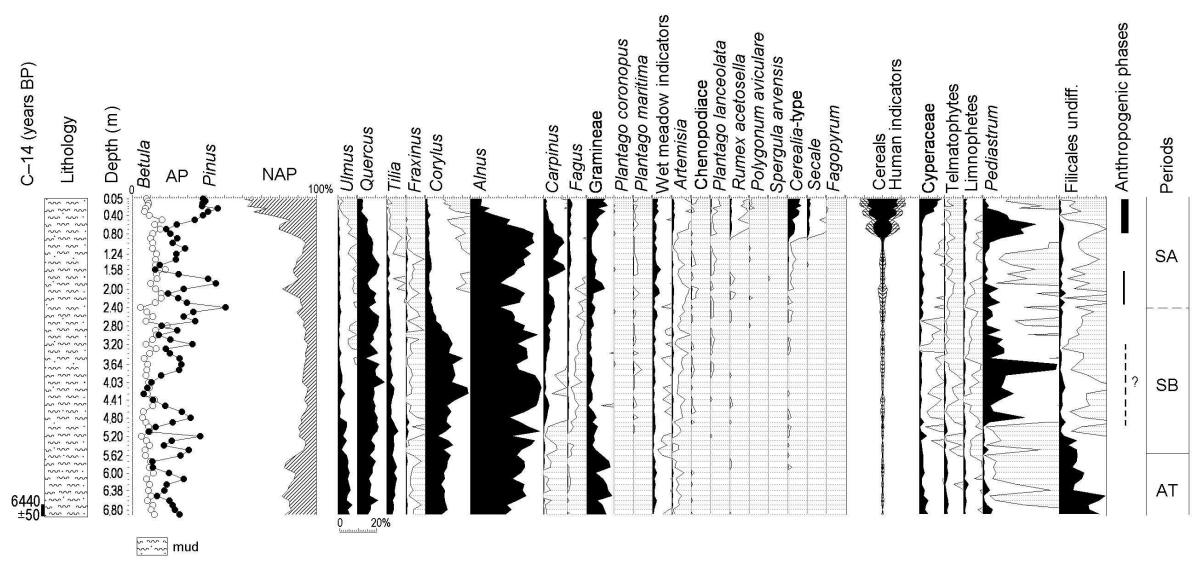

Fig. 7. Druzno Lake (altitude of the core $-0.8 \mathrm{~m}$ b.s.1.). Simplified pollen diagram.

The 4th Phase

This most intensive phase of human economic activity left its mark at all the sites, in which sediments suitable for palynological investigation were found (Figs 4, 6 - 11). In the diagrams, it was characterized mainly by an increase in the quantity of pollen grains of species related to both animal husbandry and agriculture. Apart from a visible increase of Cerealia-type and Triticum a clear increase in the quantity of rye (Secale) pollen grains is registered. It is a well known fact that in this period rye was farmed separately in the area of northern Poland (LATAŁOWA, 1994; 1995). The occurrence of a percentage of pollen grains of cornflower (Centaurea cyanus) is also evidence of agricultural development. Single occurrences of buckwheat (Fagopyrum) pollen grains indicate the possibility that it was grown in this area. Almost all diagrams present a significant increase in pine (Pinus). This is connected with a decreased presence of other trees and with the increase in NAP species. This phase begins in Early Medieval times. 


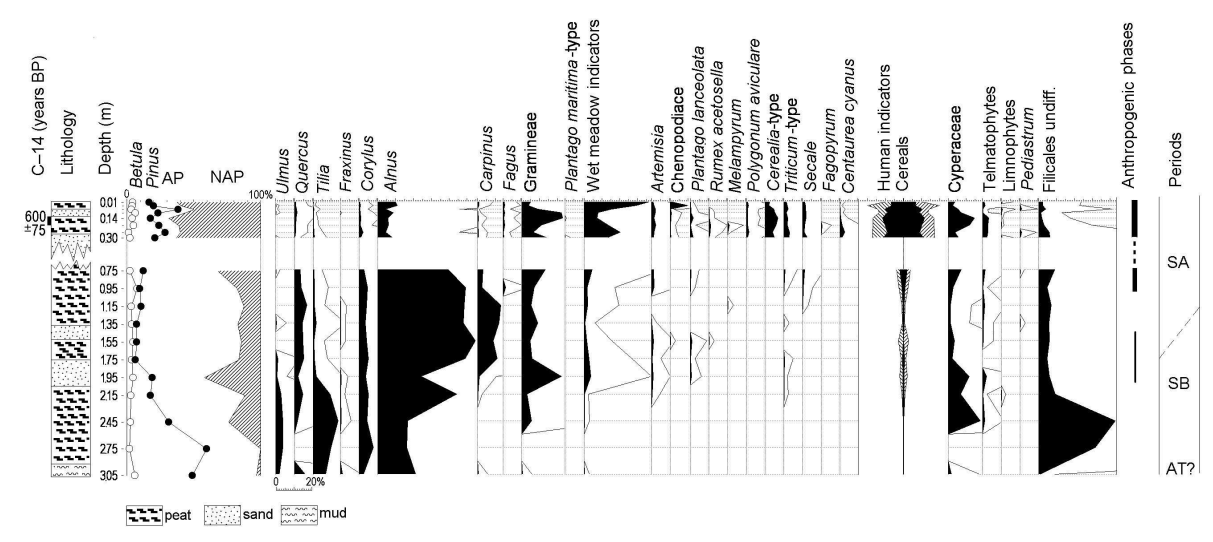

Fig. 8. Gizdepka (site altitude - $0.01 \mathrm{~m}$ b.s.1.). Simplified pollen diagram.

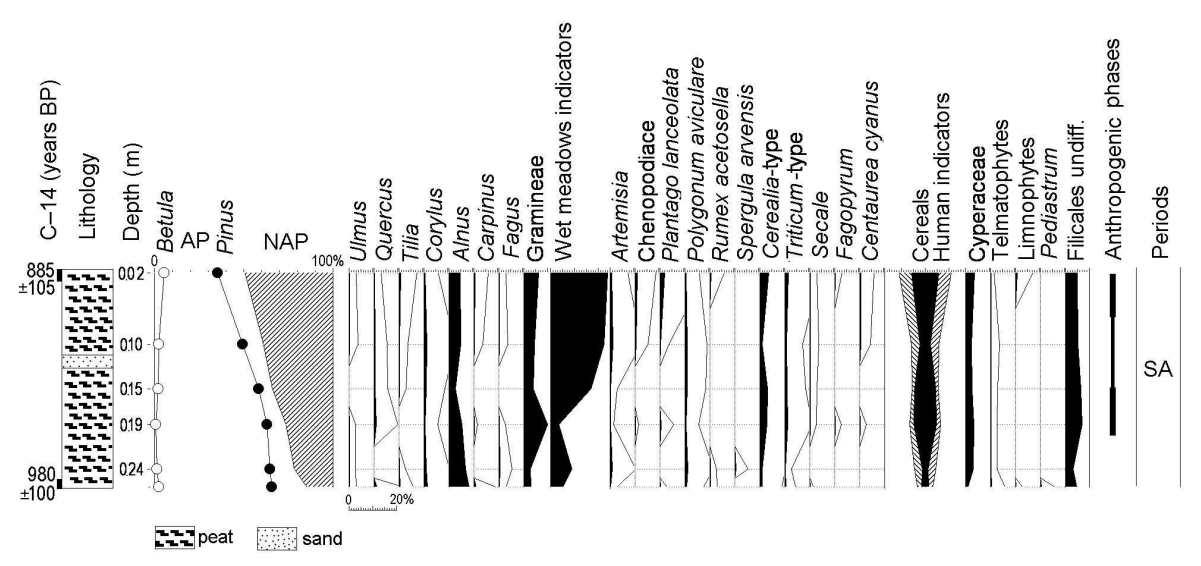

Fig. 9. Beka (site altitude $-0.11 \mathrm{~m}$ a.s.1.). Simplified pollen diagram.

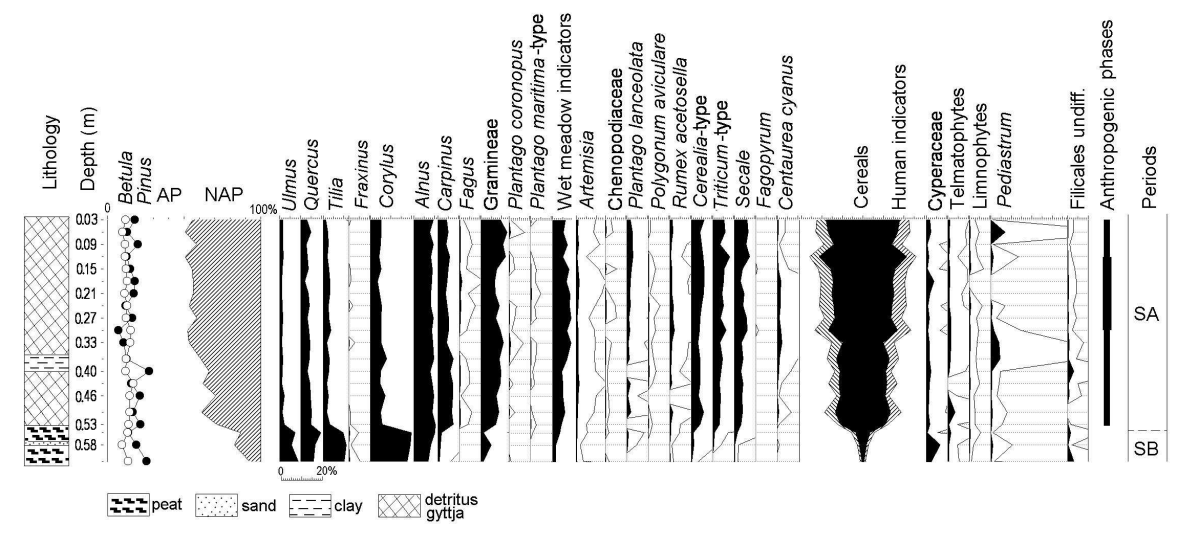

Fig. 10. Węgry (site altitude - $40.0 \mathrm{~m}$ a.s.1.). Simplified pollen diagram. 


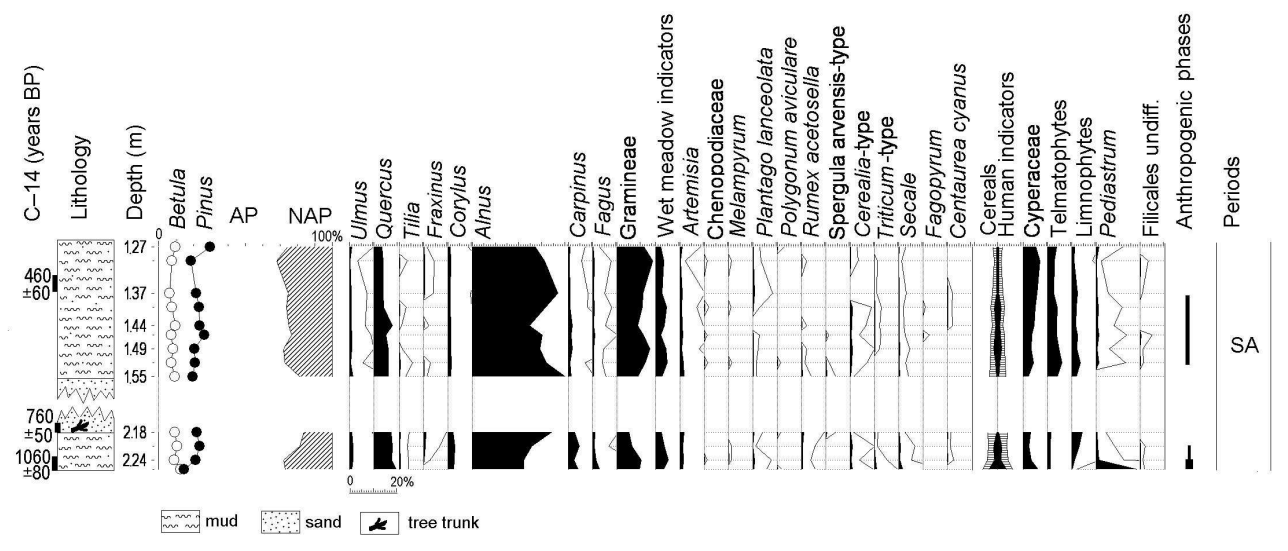

Fig. 11. Stegna (site altitude $-0.3 \mathrm{~m}$ a.s.1.). Simplified pollen diagram.

\section{Discussion}

The traces of the earliest settlement phase in the palynological analyses of the sediments investigated, was evident only from the Puck Bay area (sites: the Rzucewo Headland and the Puck Bay $6 / 2001)$. Its time of occurrence is determined through palynological analyses and radiocarbon dating to be the end of the Atlantic Period (ca. 5500 years B.P.). It is known that in this period the Baltic Sea level was approximately 5-3 $\mathrm{m}$ lower than at present (UŚCINOWICZ; MIOTK-SZPIGANOWICZ 2003). The depression of what is now the Puck Lagoon was covered by lakes; and marshy and swampy areas prevailed in the upland foothills. A rise in sea-level speeded up the peat forming processes and the development of wetland habitats in the region (UŚCINOWICZ; MIOTK-SZPIGANOWICZ， 2003; UŚCINOWICZ et al., 2007). In accordance with archaeological data, these early traces of human economic activity are related to the Paraneolithic Culture, whose economic activities have been mainly connected with fishing and hunting (KRÓL, 1997).

It is known that at the end of the Atlantic Period the Vistula Lagoon (Fig. 1) occupied its greatest extent (ZACHOWICZ; KĘPINSKA 1987). The area of the Vistula Delta was much smaller than at present and was characterized by the prevalence of swampy habitats considerable sensitive for hydrological changes caused mainly by the activity of the Vistula River. Certainly the area was unfavourable to human economic activity.

At the beginning of the Subboreal Period, the sea level was ca. $2.8 \mathrm{~m}$ below the present-day level (UŚCINOWICZ, 2003; UŚCINOWICZ; MIOTK-
SZPIGANOWICZ, 2003; UŚCINOWICZ et al., 2007). The rising sea level caused the lakes, which lay in the depressions of the then Puck Lagoon, to be gradually converted into a brackish/marine lagoon. The settlement of the second anthropogenic phase developed after these changes in the environment (UŚCINOWICZ; MIOTK-SZPIGANOWICZ, 2003). At the same time the deposition of the Vistula sediments reduced the preponderance of waterlogged sediments in parts of the Delta. Traces of Neolithic settlement are palynologically visible both in the area of the Puck Lagoon and in the Vistula Delta area (Fig. 12). The landward advance of the Gulf of Gdańsk shoreline coincides with the development of a Neolithic culture characteristic of this region, called the Rzucewo Culture, which according to archaeological dating lasted from ca. 2400 to 1700 years B.C. (about 4400-3700 years B.P.) (KRÓL, 1997). From archaeological investigations it is known that the main activities of the people of this culture were fishing, seal hunting and the collection and processing of amber. The existence of the Rzucewo Culture settlements depended to a large extent on the sea level. People of this culture were also familiar with primitive agriculture and swine and cattle breeding, although these types of economic activity, which dominated in the Neolithic cultures of other regions, did not play a significant role in this area. The impact on the environment resembled that of the Mesolithic economy rather than that of the Neolithic Age, hence traces of this activity are only poorly visible in the pollen diagrams (MIOTK-SZPIGANOWICZ, 1997; MIOTK-SZPIGANOWICZ ; UŚCINOWICZ 2003).

At the end of the Subboreal Period, the sea level was ca. 1.0-1.1 m below the present one and during the Subatlantic Period it rose very gradually 
(Fig. 2). The Vistula Barrier became more stable and areas of dry land increased in the Vistula Delta area. This facilitated a potential increase in the area of the habitat suitable for cultivation. This is clearly visible in the Vistula Delta area where the palynological data indicate an increase in human economic activity such as to allow us to distinguish the third anthropogenic phase (Fig. 12). According to Latałowa $(1994,1995)$ it was a period of intensive deforestation as previously forested areas were taken over for farming. On the other hand, archaeological investigation shows that at the turn of the era, under the influence of the expansion the Roman Empire into Central Europe, Eastern Pomerania came within the orbit of intensive commercial exchange with southern Europe. The socalled Amber Route, which linked the mouth of the Vistula to the Roman provinces, was functioning. That is why amber harvesting could prove to be a more profitable activity than agriculture. This may explain the relatively slow development of animal husbandry and agriculture on the shores of the Gulf of Gdańsk, where fishing was still the dominant activity.

The data quoted and the sea-level curve (Fig. 13) indicate that the type of economic activity in the third phase (Fig. 12) was closely related to the sea level. It is known that in the Baltic coastal zone of Poland one of the most important periods of human impact was that of the late Bronze and early Iron Ages, i.e. between 3100-2400 years B.P. (LATAŁOWA 1997). In the area investigated there is no palynological evidence of any human impact during the late Bronze Age. Such a situation was probably due to the high water level at that time (Fig. 13) and, because of it, to a lack of suitable habitats for more intensive human economic activity.

The fourth anthropogenic phase (Fig. 12) is related to the Early Middle Ages, when from the middle of the 9th to the 12th century, an intensification of settlement was observed.

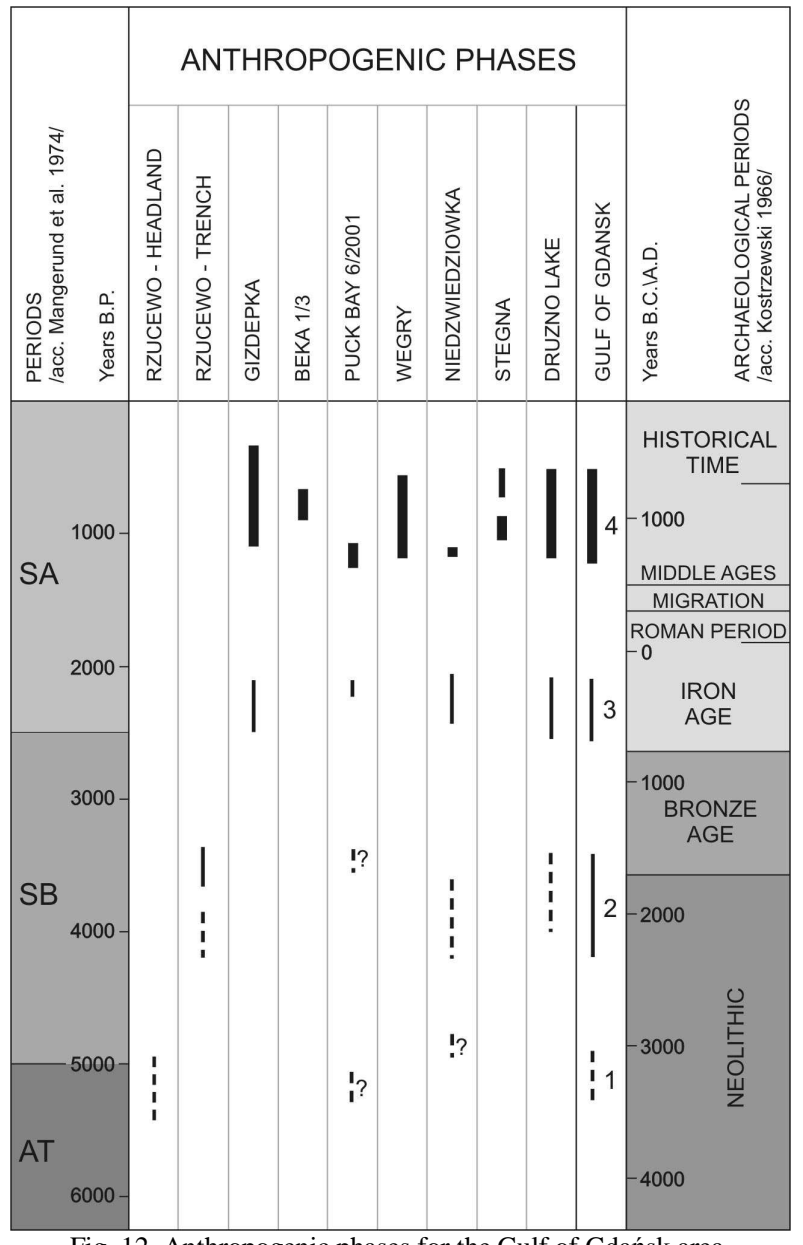

Fig. 12. Anthropogenic phases for the Gulf of Gdańsk area. 


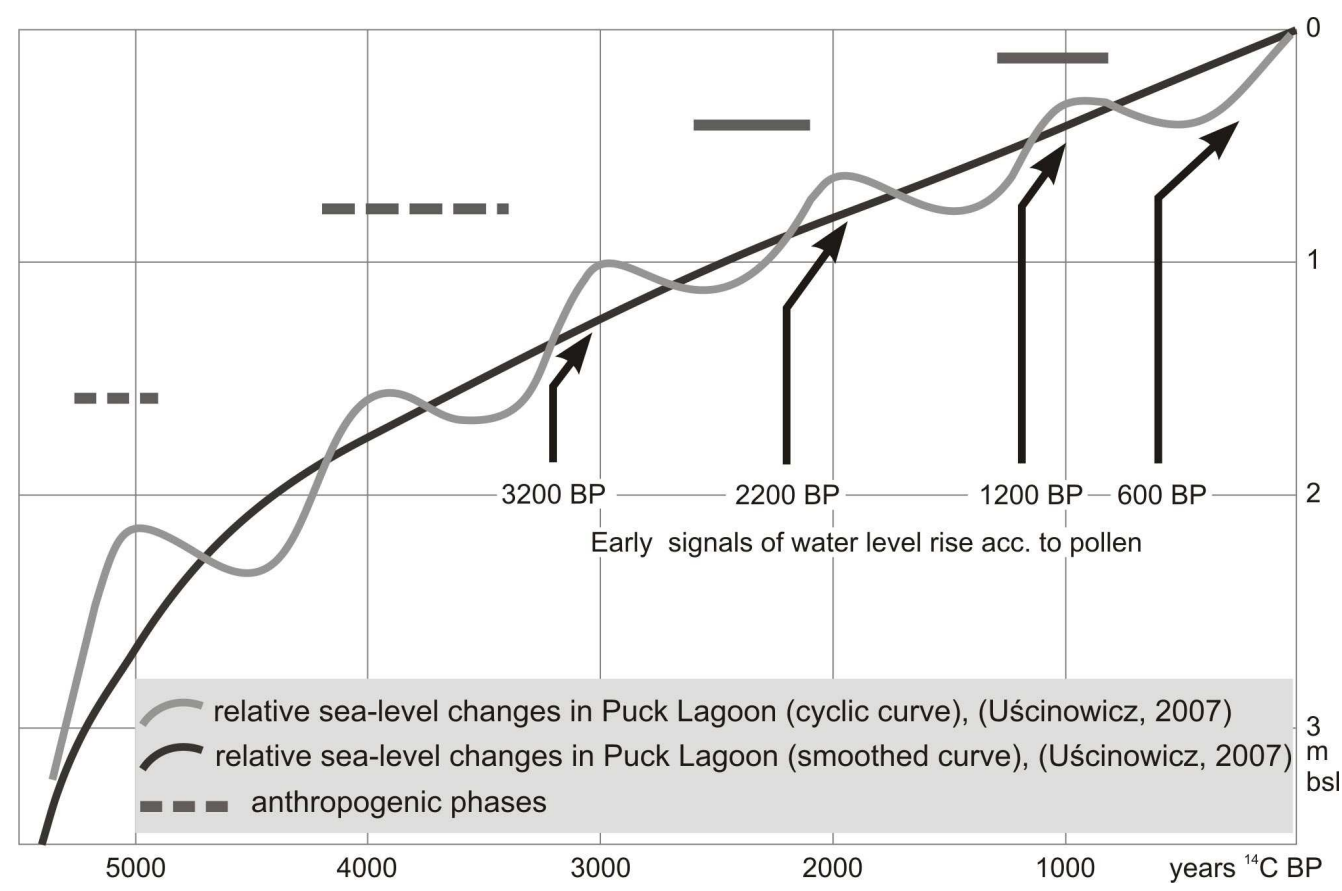

Fig. 13. The Puck Lagoon relative sea level curve (UŚCINOWICZ, 2007) with anthropogenic phases of the Gulf of Gdańsk area.

Numerous settlements emerged around fortified towns; they were located in low areas, often at the edges of a morainic plateau or on river banks (KRÓL, 2002, 2003).

Palynological data indicates a clear extension of cereal farming during this phase. We can suppose that it began ca. 1000 years B.P. because at that time the sudden increase in cultivation indicators is observed across the entire Gulf of Gdańsk region (LATAŁOWA, 1982, 1995; TOBOLSKI, 1987; ZACHOWICZ; KĘPINSKA, 1987). At that time the barriers were strong enough to separate the lagoons from the sea and to dry out the area of the Vistula Delta. In general, however, agriculture was not very intensive in the area under investigation. A different situation is to be observed at the Wegry site (Fig. 10) lying on the morainic upland south of the Vistula Delta.

Fluctuations in the intensity of economic activity are to be observed within this phase. The best record of these fluctuations may be seen at the Lake Druzno site (Fig. 7) - the local sedimentary basin within the Vistula Delta. The sites like Gizdepka (Fig 2, 8), located on the lagoon shore, and Stegna (Fig. 2, 11), located on the Vistula Delta, were susceptible to natural disasters such as storm surges or flooding. An important factor in the coastal area was shoreline erosion for natural and anthropogenic reasons, which could have caused the destruction of the medieval Puck Harbour (LATAŁOWA; BADURA 1998). Such natural disasters might explain the rapid decreases in human indicators observed in the pollen diagrams (Figs 8, 11).

\section{Conclusions}

- According to the results of palynological investigations, four phases of human impact were distinguished on the coast of the Gulf of Gdańsk.

- Human economic activity during the two earliest phases appears to have been connected with fishing, seal-hunting and amber-working and closely related to the rising sea level (Littorina, Atlantic/Middle Holocene transgression). This kind of settlement could only have existed in close proximity to the sea shore. The people of the Paraneolithic and Rzucewo Cultures had to retreat southwards when the sea level rose.

- The two later phases arose and developed mainly during the high sea level stands of the Subboreal and Subatlantic Periods (post-Littorina, Late Holocene regressions) but their character was still strongly related to the coastal environments. Settlement was connected with the dry habitats whose areas increased after the development of the barriers. 
- A very close relationship between human activity and sea-level change was evident throughout the coastal area of the Gulf of Gdańsk. However, in the area of the present-day Puck Bay it was more closely connected with the consolidation of the barrier, while in the Vistula Delta it was more closely related to the development of the delta.

- Settlement on the Gulf of Gdańsk coast was less dependent on general climatic changes than on the sea-level oscillations which influenced the formation of adequate settlement habitats in close proximity to the sea.

\section{REFERENCES}

BARD, E.; HAMELIN, B.; ARNOLD, M.; MONTAGGIONI, L.; CABIOCH, G.; FAURE, G.; ROUGERIE, F. Deglacial sea-level record from Tahiti corals and timing of global meltwater discharge. Nature, v. 382 , n. 6588 , p. $241-244,1996$.

BEHRE, K.-E. The interpretation of anthropogenic indicators in pollen diagrams. Pollen et Spores, v. 23, n. 2, p. $225-$ $245,1981$.

BERGLUND, B. ,E. Littorina transgressions in Blekinge, south Sweden, a preliminary survey. Geologiska Foreningens I Stockholm Forhandlingar, v. 93, p. 625652,1971 .

BERGLUND, B. E. Pollen analysis. In: BERGLUND, B.E (Ed.). Palaeohydrological changes in the temperate zone in the last $\mathbf{1 5 0 0 0}$ years. Project 158 , Subproject B, 2, p. 133-167, 1979.

BLANCHON P.; SHAW, J. Reef drowning during the last deglaciation: Evidence for catastrophic sea-level rise and ice-sheet collapse. Geology, v. 23, n. 1, p. 4-8, 1995.

BOGACZEWICZ-ADAMCZAK, B.; MIOTK, G. From biostratigraphical studies of the Vistula Lagoon [Eng. Summ.]. Peribalticum III, Gdanskie Towarzystwo Naukowe, 113-127.

BOGACZEWICZ-ADAMCZAK, B.; DRWAL, J GOŁEBIEWSKI, R.; KRÓL, D.; MIOTKSZPIGANOWICZ, G.; WOZNIAK, P. P. Influence of changes in natural environment on development of Stone Age settlement in Pobrzee Kaszubskie. Quat. Stud Poland, p. 51-59, 1999. Special issue.

DIGERFELDT, G. Investigations of Littorina transgressions in the ancient lagoon Barsebäckmossen, western Skåne. University of Lund, Department of Quaternary Geology, 1975. Report 7.

FAIRBANKS, R. G. A 17,000-year glacio-eustatic sea level record: influence of glacial melting rates on the Younger Dryas event and deep-ocean circulation. Nature, v. 342, p. 637-642, 1989

FAEGRI, K.; IVERSEN, J. Podrecznik analizy pyłkowej Wydawnictwo Geologiczne, Warszawa, 1978. 250 p.

GRAMSCH, B. Late Mesolithic settlement and sea level development at the Littorina coast- sites RalswiekAugustenhof and Lietzow-Buddelin. Greifswalder Geographische Arbeiten, 27, Holocene Evolution of the South-Western Baltic Coast - Geological, Archaeological and Palaeo-environmental aspects. FIELD MEETING OF INQUA SUBCOMMISION, 5. September, 22-27, 2002. p. 37-47.
KOSTRZEWSKI, J. Pradzieje Pomorza. WrocławWarszawa-Krakow, 1966. $187 \mathrm{p}$.

KRAMARSKA, R.; USCINOWICZ, SZ.; ZACHOWICZ, J. 1995. Origin and evolution of the Puck Lagoon. J. coastal Res., Special Issue 22, p. 187-191, 1995.

KRAMARSKA, R.; USCINOWICZ, SZ; ZACHOWICZ, J.. Geology and evolution of the Puck Lagoon. In: UŚCINOWICZ, SZ.; ZACHOWICZ, J. (Ed.). Rapid transgressions into semi enclosed basins REGIONAL CONFERENCE, EUROPE, 2003. Abstracts and Excursion Guide-Book. Polish Geological Institute, Gdansk, 2003, 103-106.

KRÓL, D. Siedlungen der Rzucewo-Kultur in Oslonino, Fundstelle 2 in Rzucewo, Fundstelle 1, gem. Puck. In: JANKOWSKA, D. (Ed.). Die Trichterbecherkultur. Neue Forschungen und Hypothesen, II, Poznan, 111-117, 1991.

KRÓL， D. Excerpts from Archeological Research at Rzucewo, Puck Region. In: KRÓL, D. (Ed.). The Built environment of coast areas during the Stone Age. THE BALTIC SEA-COAST LANDSCAPES SEMINAR. Session No.1, Gdansk, 1997. p. 135-150.

KRÓL, D. Archeologiczne dziedzictwo kulturowe strefy nadmorskiej. In: DETTLAFF, J. (Ed.). Materiały z sesji naukowej: Gmina Puck. Z pradziejów regionu nadmorskiego Zeszyty Gminy Puck, 2, 40-46, 2002.

KRÓL, D. The elements of settlements in Rzucewo Culture (Rzucewo, Władysławowo-Ostrowo). In: USCINOWICZ, SZ.; ZACHOWICZ, J. (Ed.). Rapid transgressions into semi enclosed basins REGIONAL CONFERENCE, EUROPE, 2003. Abstracts and Excursion Guide-Book. Polish Geological Institute, Gdansk, p. 113-119, 2003.

LATAŁOWA, M. Postglacial vegetational changes in the eastern Baltic coastal zone of Poland. Acta Palaeobotanica, vol. 22, n. 2, p. 179-249, 1982.

LATAŁOWA, M. Type region P-t: Baltic Coastal Zone. Acta Palaeobotanica, v. 2, p. 103-108, 1989.

LATAŁOWA, M. Gospodarka mezolitczna i początki rolnictwa na obszarze polskiego Pobrzeza Bałtyku w świetle danych palinologicznych. Pol. botanical Stud., Guidebook Series 11, 135-153, 1994.

LATAŁOWA, M. Zarys problematyki palinostratygrafii holocenu polskiego pobrzeza Bałtyku [Engl. Sumary]. In: FLOREK, W. (Ed.). Geologia i Geomorfologia Pobrzeza i Południowego Bałtyku, (2), WSP Słupsk, 111-125, 1995.

LATAŁOWA, M. Wpływ osadnictwa schyłku epoki brazu i wczesnej epoki zelaza na póznoholocenska historie lasów na Pobrzezu (Impact of the late Bronze and Early Iron Age settlement on the late Holocene history of forests in the Baltic coastal zone of Poland). In: FAŁTYNOWICZ, W.; LATAEOWA, M.; SZMEJA, J. (Ed.). Dynamics and conservation of the Pomerania vegetation. Bogucki Wyd. Nauk., Gdansk-Poznan, 113124, 1997.

LATAŁOWA, M.; TOBOLSKI, K. Type region P-u: Baltic Shore. Acta Palaeobotanica, v. 29, n. 2, p. 109-114, 1989.

LATAŁOWA, M.; BADURA, M. Wstepne wyniki badan paleoekologicznych w rejonie wczesnosredniowiecznego portu zatopionego w Zalewie Puckim. Pomerania Antiqua. T. XVII, Gdansk, 321-342, 1998. 
LÜBKE, H. 2002. Submarine Stone Age settlements as indicators of sea level changes and the coastal evolution of the Wismar Bay Area. Greifswalder Geographische Arbeiten, 27, Holocene evolution of the South-Western Baltic coast - Geological, Archaeological and Palaeoenvironmental aspects. FIELD MEETING OF INQUA SUBCOMMISION, 5., Sept., 22-27.2002. p., 203-211.

MAJEWSKI, A. Hydrographic development of Vistula Delta in historical times. [Eng. Summ.]. Przeglad Geofizyczny, XIV(XXII), z. 1, 3-40, 1969.

MANGERUD, J; AERUNDERSEN, S. T; BERGLUND B. E.; DONNER, J. J. Quaternary stratigraphy of Norden, a proposal for terminology and classification. Boreas, Oslo, v. 3, p. 109-126, 1974.

MIOTK-SZPIGANOWICZ, G., Results of palynological investigations in the Rzucewo area. In: KROLL, D. (Ed.). The built environment of coast areas during the Stone Age. THE BALTIC SEA-COAST LANDSCAPE SEMINAR, Session 1, Gdańsk, p. 153-162, 1997.

MIOTK-SZPIGANOWICZ, G., UŚCINOWICZ, SZ. 2003. Environment around Neolithic seal hunters settlement in Rzucewo. In: UŚCINOWICZ, SZ.; ZACHOWICZ, J. (Ed.). Rapid transgressions into semi enclosed basins - REGIONAL CONFERENCE, EUROPE, 2003. Abstracts and Excursion Guide Book. Polish Geological Institute, Gdańsk, 107-112, 2003.

MOJSKI, J. E. Development of the Vistula River delta and evolution of the Baltic Sea, an attempt at chronological correlation. In: WINTERHALTER, B. (Ed.). The Baltic Sea Geological Survey of Finland, Special Papers 6, p. 39-51, 1988

MOJSKI, J. E. 1990., The Vistula river delta. In: STARKEL, L; WISNIEWSKI, E. (Ed.). The evolution of the Vistula River Valley during the last 15000 years, Part III. Geogr. Stud., Special Issue n. 5, p. 126-153, 1990.

MÖRNER, N. A. Eustatic changes during the last 8000 years in view of radiocarbon calibration and new information from the Kattegatt region and other northwestern European coastal areas. Palaeogeogr., Palaeoclimatol., Palaeoecol., v. 19, p. 63-85, 1976.

MÖRNER, N., A. Late Quaternary sea-level changes in north-western Europe: a synthesis. Geologiska Förhandlingar, v. 100 , p. 381-400, 1980

OSTOJA-ZAGÓRSKI, J. From studies on the economic structure at the decline of the Bronze Age and the Hallstatt period in the north and west zone of the Odra and Vistula Basins. Przegl. Archeol., v. 22, p. 123-150, 1974.

POMIAN, I.; LATAŁOWA, M.; ŁECZYNSKI, L; BADURA, M. Water or Land? Preliminary results of an interdisciplinary project of paleoenvironmental reconstruction at the site of medieval harbour in Puck $(\mathrm{N}$. Poland). INTERNATIONAL SYMPOSIUM ON BOAT AND SHIP ARCHAEOLOGY, 8. , Gdansk, 2000. Proceedings ... p. 27-36, 2000.
RALSKA-JASIEWICZOWA, M., LATAEOWA, M., WASYLIKOWA, K., TOBOLSKI, K., MADEYSKA, E., WRIGHT, H., TURNER, CH. (Ed.). Late Glacial and Holocene history of vegetation in Poland based on isopollen maps. W. Szafer Inst. of Botany Polish Academy of Sciences, Kraków, 2004. .

TOBOLSKI, K. Holocene vegetational development based on the Kluki reference site in the Gardna-Łeba Plain, Acta Palaeobotanica, v. 27, n. 1, p. 179-222, 1987.

TOBOLSKI, K. Holocenskie transgresje Bałtyku w swietle badan paleoekologicznych Niziny Gardziensko-Łebskiej. Studia i Materiały Oceanologiczne 56. Geologia Morza v. 4, p. 257-265, 1989.

UŚCINOWICZ, SZ. Quaternary of the Gdansk Basin. Prace PIG CXLIX, p. 67-70, 1995.

UŚCINOWICZ, SZ. Relative sea level changes, glacioisostatic rebound and shoreline displacement in the Southern Baltic. Pol. Geol. Inst. Spec. Pap., v. 10, p. 179, 2003.

UŚCINOWICZ SZ; ZACHOWICZ, J. Geological map of the Baltic Sea bottom, 1:200000, sheet Gdansk. Panstw. Inst. Geol. Warszawa, 1992.

UŚCINOWICZ, SZ., MIOTK-SZPIGANOWICZ, G. 2003. Holocene Shoreline Migration in the Puck Lagoon (Southern Baltic Sea) based on the Rzucewo Headland case study. Landform Analysis, v. 4, 81-95, 2003.

UŚCINOWICZ SZ; ZACHOWICZ J.; MIOTKSZPIGANOWICZ G.; WITKOWSKI A. 2007 Southern Baltic sea-level oscillations: New radiocarbon, pollen and diatom proof of the Puck Lagoon. In: HARFF, J.; W. W.; HAY, W. W.; TETZLAFF, D. M. (ED.). Coastline changes: Interrelation of climate and geological processes. . Geol. Soc. Am. Spec. Pap., n. 426, p. 1-16, 2007.

ZACHOWICZ, J., PRZYBYŁOWSKA-LANGE, W., NAGLER, J. The Late-Glacial and Holocene vegetational history of the _uławy Region, N. Poland. A biostratigraphic study of Lake Druzno sediments. Acta Palaeobotanica, v. 22, n. 1, p. 141-161, 1982.

ZACHOWICZ, J.; KEPINSKA, U. The palaeoecological development of Lake Druzno (Vistula Deltaic Area). Acta Palaeobotanica, v. 27, n. 1, p. 227-249, 1987.

ZACHOWICZ, J.; UŚCINOWICZ, SZ; MIOTKSZPIGANOWICZ, G. Southern Baltic Sea level oscillation inferred from fact of the Puck Lagoon study. IGC, 32., August 20-28, 2004, Florence, Italy. Scientific Sessions, Abstracts (part 2), p. 257-259.

(Manuscript received 03 June 2009; revised 15 December 2009; accepted 25 March 2010) 